\title{
Japan faces new questions on HIV in blood...
}

Tokyo. A renewed controversy over the delays in Japan's introduction of heat-treated blood coagulants, which resulted in thousands of Japanese haemophiliacs being infected with HIV, has been stirred up by a television documentary transmitted by the Japan Broadcasting Corporation(NHK). But the programme has raised more questions than it has provided answers.

As in France, where government officials and scientists have been jailed because of delay in introducing heat-treated products, Japan did not allow the use of coagulants treated with heat to kill HIV and other viruses until 1985, more than two years after their introduction in the United States.

Between 1983 and 1985, there was a boom in Japanese imports of non-heattreated products from the United States, and many of Japan's 5,000 haemophiliacs were infected as a result. Two groups of haemophiliacs in Tokyo and Osaka are now suing the government and private companies.

The NHK programme revealed strong differences of opinion between officials of the Ministry of Health and Welfare and scientists advising the government on how to deal with AIDS. In June 1983, a division of the ministry's pharmaceutical affairs bureau set up an AIDS study group headed by Takeshi Abe of Teikyo University to help formulate policy on blood products.

Atsuaki Gunji, head of the division, surprised some members of the group when he suggested that the ministry was prepared to circumvent regulations and allow the emergency import of heat-treated products.

But Abe opposed this idea, fearing that doctors would be blamed for any sideeffects from the use of heat-treated products that had not undergone clinical trials in Japan. In November 1983, Abe's view won the day and the ministry decided to continue the use of non-heat-treated products while carrying out clinical trials of heat-treated ones, a process that took nearly two years.

The NHK has now shown that a number of incidents in 1983 might have alerted the study group to the immediate threat of AIDS, but for reasons that remain unexplained, no quick action was taken.

For example, 11 days before the study group was established, Gunji was notified by the US company Travenol that it wanted

\section{. . . as German executives are charged}

Munich. The director and four staff members of a company found to have sold HIVinfected blood products were last week charged with grievous bodily harm, a crime that carries a maximum five-year prison sentence in Germany.

Between 1987 and October 1993, when the company was closed down, UB Plasma, based in Koblenz, supplied hospitals with more than 70,000 litres of plasma that had been inadequately tested for HIV and the hepatitis viruses. The company had tested pooled rather than individual samples of plasma, and had then assessed the results of the colorimetric tests by eye.

As a result, three patients became infected with HIV following transfusions, one of whom has since died from his original illness. A single blood donor was responsible for all three cases.

UB Plasma also sold 43,000 litres of 'industrial plasma', worth DM10 million (US\$5.9 million), to eight different companies between 1988 and 1993. This plasma was used by the companies to make pharmaceutical blood products, and any HIV infection is likely to have been destroyed in standard heat-inactivation processes.

No date for the trial has yet been set, but it will take place in the state of RheinlandPfalz, as responsibility for overseeing industrial standards lies with the Land, rather than the federal government.

There may be further charges against UB
Plasma. The daily newspaper Bild reported on 14 February that in March 1992 the company sold its licence to manufacture and sell pharmaceutical blood products to a small company called Octapharma from Langenfeld for DM100,000.

But it continued to make products and sell them under its own name. The ministry of health in Rheinland-Pfalz took no action, claims the newspaper, even though it had been informed of this illegal action by the Bundesgesundheitsamt, the federal health agency, in July 1992.

Alison Abbott to recall blood products sent to Japan that were suspected of being contaminated by the blood of an AIDS sufferer; they were returned to the United States in August 1983. A few months later, another US company, Cutter, recalled several thousand bottles of coagulant for the same reason.

Yuichi Shiokawa, of the AIDS study group, when shown a government document describing the recall of the Travenol products by NHK, said it was the first time he had seen it. He said that, if the group had known of Travenol's move, its discussion of emergency imports might have been different.

Gunji, when asked why the study group was not informed, did not give a clear answer but implied that it was not his decision. But his immediate superior at that time, Kazumi Mochinaga, then head of the pharmaceutical affairs bureau, suggested the matter had been Gunji's responsibility.

Another puzzling incident revolves around the first AIDS patient in Japan. In 1983, Abe had a haemophilia patient with typical AIDS symptoms but other members of the study group did not accept Abe's view that the patient had AIDS. The ministry consulted an official of the US Centers for Disease Control who said the patient was undoubtedly an AIDS sufferer.

The patient died in July 1983. But the ministry refused to recognize him as an AIDS sufferer until after it had announced (in March 1985) that Japan's first AIDS patient was a homosexual recently returned from the United States.

A ministry official said that cases of suspected HIV infection in haemophiliacs were not announced earlier to avoid a "big panic" and to ensure a "smooth landing" when the announcement was made. Abe says his hands were tied by his colleagues' decision, and refused to comment on why he did not support immediate changes in the use of coagulants.

David Swinbanks

\section{. . . and Le Monde points a finger at the US}

Paris. The French newspaper Le Monde has claimed that the United States deliberately continued to distribute clotting factors that it knew were contaminated with human immunodeficiency virus to haemophiliacs for economic reasons.

The newspaper last week published extracts of the minutes of a meeting of the Public Health Service (PHS) Task Force on AIDS on 6 May 1985, chaired by James O. Mason - then director of the Centers for Disease Control in Atlanta, and later Deputy Secretary of Health - showing that manufacturers of clotting factors were continuing to distribute products that had not been inactivated by heating whereas heat-inactivated products were available.
The minutes add that the Food and Drug Administration (FDA) intended to put pressure on the manufacturers to stop the practice. Le Monde also cites a report to the French government which alleges that transfusion centres in the United States continued to supply unheated products to haemophiliacs already undergoing treatment, and reserved heated products for those beginning treatment, for economical reasons.

The newspaper also quotes Gerald Quinnan from the FDA, as saying that this distinction between groups of patients was made without taking into account whether individual patients were seropositive or seronegative.
Declan Butler 